\title{
STUDY OF PERSONAL HYGIENE, NUTRITIONAL AND MORBIDITY PROFILE OF SCHOOL CHILDREN IN RURAL AREA OF KHAMMAM DISTRICT, ANDHRA PRADESH
}

\author{
Aditya S. Berad ${ }^{1}$, B. Chandra Sekhar Reddy², B.P. Ravi Kumar³, Venu Bolisetti4
}

\section{HOW TO CITE THIS ARTICLE:}

Aditya S Berad, B Chandra Sekhar Reddy, BP Ravi Kumar, Venu Bolisetti. "Study of personal hygiene, nutritional and morbidity profile of school children in rural area of Khammam district, Andhra Pradesh". Journal of Evolution of Medical and Dental Sciences 2013; Vol2, Issue 34, August 26; Page: 6402-6405.

ABSTRACT: BACKGROUND: Majority of the health problems of school children can be prevented by promotion of hygiene and sanitation through health education of school children, teachers and parents. OBJECTIVES: 1 . To find out the status of personal hygiene among the primary school children. 2. To study the nutritional and morbidity profile of the school students. MATERIALS AND METHODS: A cross sectional study was conducted among primary school students in rural area of Khammam district, A.P. RESULTS: the study included 180 primary school children (105 boys and 75 girls). The status of personal hygiene was better among girl as compared to boys when it came to clean and combed hairs (82.66 vs. 66.66\%, p<0.05), clean clothes (94.66\% vs.79.04\%, p<0.05), clean teeth $(89.33 \%$ vs.80.95\%, $\mathrm{p}<0.05)$, use of soap for hand washing at school $(86.66 \%$ vs.72.38\%, p<0.05), hand washing after toilet (93.33\% vs. 80.95\%, p<0.05). Anemia (43.88\%) and malnutrition $(31.66 \%)$ was found to be common among the school children. CONCLUSIONS: The government health services should regularly undertake school health checkup and health education session in the schools for a wider coverage. Periodic appraisal of school staff and parents of the school students needs to be undertaken in aspects of health of the children.

INTRODUCTION: School health is an important branch of community health. In 1960, the government of India constituted a School Health Committee to assess the standards of health and nutrition of school children and suggest ways and means to improve them. ${ }^{1}$ The committee recommended the need for medical examination of pupils and of school nutrition program. Schools are sacred because they provide an environment for learning skills and for development of intelligence that can be utilized by students to achieve their goals in life. School is a place where health education regarding important aspects of hygiene, environment and sanitation, as well as social customs, is being imparted.

There are 6.3 lakh schools in India, with 128.3 million children in primary schools and about 50 million in upper primary schools. ${ }^{2}$ It is a fact that only $8 \%$ of the schools have sanitation facilities in school premises, only $44 \%$ have water supply facilities, $19 \%$ have urinals and $8 \%$ have lavatory facilities. Under these conditions, schools and community environment become unsafe places where diseases are transmitted. ${ }^{3}$

The present study was undertaken among primary school children of rural area of Khammam district, Andhra Pradesh, with the following objectives:

1. To find out the status of personal hygiene among the primary school children.

2. To study the nutritional and morbidity profile of the school students. 
MATERIALS AND METHODS: The study was undertaken in three Zilla Parishad Primary schools in Villages of Raghunathpalem Mandal of Khammam district in the month of July 2013, after taking necessary permission from the Principals of the school. The base line health check-up of all the 180 students in the school was carried out with the help of pretested and structured questionnaire to find out the status of personal hygiene and related morbidities. The age of the participants ranged from 5-11 years (mean Age 7.2 years). The check-up was carried out by the team of medical officers and social workers from the Department of Community Medicine, Mamata Medical College, Khammam. Data thus collected were analyzed using suitable statistical tests with the help of Epi Info version 3.2 .

RESULTS: Table 1 shows that status of personal hygiene was better among girl as compared to boys when it came to clean and combed hairs (82.66 vs. 66.66\%, p<0.05), clean clothes (94.66\% vs.79.04\%, p<0.05), clean teeth (89.33\% vs.80.95\%, p<0.05), use of soap for hand washing at school (86.66\% vs.72.38\%, p<0.05), hand washing after toilet (93.33\% vs. 80.95\%, p<0.05).

Table 1: Status of personal hygiene among school children.

\begin{tabular}{|l|c|c|c|c|c|}
\hline \multicolumn{1}{|c|}{ Indicators of personal hygiene } & $\begin{array}{c}\text { Boys } \\
(\mathbf{n = 1 0 5})\end{array}$ & $\begin{array}{c}\text { Girls } \\
(\mathbf{n = 7 5 )}\end{array}$ & $\begin{array}{c}\text { Total } \\
(\mathbf{n = 1 8 0})\end{array}$ & Z -TEST & P-value \\
\hline Clean and combed hair & $70(66.66)$ & $62(82.66)$ & $132(73.33)$ & 2.20 & $<0.05$ \\
\hline Clean and cut nail & $58(55.23)$ & $45(60.00)$ & $103(57.22)$ & 0.51 & $>0.05$ \\
\hline Clean clothes & $83(79.04)$ & $71(94.66)$ & $154(85.55)$ & 2.58 & $<0.05$ \\
\hline Clean teeth & $85(80.95)$ & $67(89.33)$ & $152(84.44)$ & 2.22 & $<0.05$ \\
\hline Use of soap for hand washing at school & $76(72.38)$ & $65(86.66)$ & $141(78.33)$ & 2.04 & $<0.05$ \\
\hline Hand washing after toilet & $85(80.95)$ & $70(93.33)$ & $155(86.11)$ & 2.22 & $<0.05$ \\
\hline Use of soap for hand washing at home & $78(74.28)$ & $62(82.66)$ & $140(77.77)$ & 1.08 & $>0.05$ \\
\hline Use of toothpaste with tooth brush & $54(51.42)$ & $46(61.33)$ & $100(55.55)$ & 1.17 & $>0.05$ \\
\hline
\end{tabular}

Figures in the parenthesis indicates percentage

It was found that $30.47 \%$ of boys and $28 \%$ of girls were suffering from some illness. Table 2 shows that vitamin A deficiency, other vitamin deficiencies and malnutrition was more in boys as compared to girls but this difference was not statistically significant $(\mathrm{p}>0.05)$. Clinically detected anemia was more common in girls than boys ( $57.33 \%$ vs. $43.28 \%$, p $>0.05$ ). Overall $43.88 \%$ of the school students were anemic, and $25.55 \%$ were suffering from vitamin A deficiency.

Table 2: Nutritional status among school children.

\begin{tabular}{|l|c|c|c|c|c|}
\hline \multicolumn{1}{|c|}{ Variables } & $\begin{array}{c}\text { Boys } \\
(\mathbf{n = 1 0 5})\end{array}$ & $\begin{array}{c}\text { Girls } \\
(\mathbf{n = 7 5 )}\end{array}$ & $\begin{array}{c}\text { Total } \\
(\mathbf{n = 1 8 0 )}\end{array}$ & Z -TEST & P-value \\
\hline Anemia & $36(43.28)$ & $43(57.33)$ & $79(43.88)$ & 1.70 & $>0.05$ \\
\hline Vitamin A Deficiency & $28(26.66)$ & $18(24.00)$ & $46(25.55)$ & 0.13 & $>0.05$ \\
\hline Other Vitamin Deficiency & $19(18.09)$ & $12(16.00)$ & $31(17.22)$ & 0.15 & $>0.05$ \\
\hline Underweight $\left(\mathrm{BMI}<5^{\text {th }}\right.$ percentile) & $34(32.38)$ & $23(30.66)$ & $57(31.66)$ & 0.12 & $>0.05$ \\
\hline Overweight (BMI <>95 $5^{\text {th }}$ percentile) & $3(2.85)$ & $1(1.33)$ & $4(2.22)$ & 1.60 & $>0.05$ \\
\hline
\end{tabular}

Figures in the parenthesis indicate percentage. 
Table 3: Morbidity status among school children

\begin{tabular}{|l|c|c|c|c|c|}
\hline \multicolumn{1}{|c|}{ Morbidity } & Boys (n=105) & $\begin{array}{c}\text { Girls } \\
(\mathbf{n = 7 5 )}\end{array}$ & $\begin{array}{c}\text { Total } \\
(\mathbf{n = 1 8 0})\end{array}$ & Z-TEST & P-value \\
\hline Diarrhea, fever, Upper RTI & $12(11.42)$ & $6(8)$ & $18(10)$ & 0.41 & $>0.05$ \\
\hline Head Lice & $6(5.71)$ & $4(5.33)$ & $10(5.55)$ & 0.38 & $>0.05$ \\
\hline Scabies & $3(2.85)$ & $2(2.66)$ & $5(2.77)$ & 0.12 & $>0.05$ \\
\hline Multiple boils & $7(6.66)$ & $5(6.66)$ & $12(6.66)$ & 0.16 & $>0.05$ \\
\hline Dental Caries & $2(1.90)$ & $1(1.33)$ & $3(1.66)$ & 0.86 & $>0.05$ \\
\hline History of worm infestation & $2(1.90)$ & $3(4.00)$ & $5(2.77)$ & 2.93 & $<0.05$ \\
\hline Total & $32(30.47)$ & $21(28.00)$ & $53(29.44)$ & 0.12 & $>0.05$ \\
\hline
\end{tabular}

Figures in the parenthesis indicate percentage.

Boys had more morbidities (30.47\%) as compared to girls (28\%) but this difference was not found to be significant. Significant difference was observed among boys and girl students about history of worm infestation with worm infestation more among girls (4\%) as compared to boys $(1.9 \%)$.

DISCUSSION: A similar study carried out in South Kolkata ${ }^{4}$ found that the status of personal hygiene among girls was better compared to boys when it came to clean and trimmed nails $(77.8 \%$ vs. $50.5 \%$ ), clean hands and skin ( $92.6 \%$ vs. $68.9 \%$ ), which are similar to the findings of the present study. However in the South Kolkata study ${ }^{4}$ boys had better clean and combed hairs as compared to girls $(92.23 \%$ vs. $85.19 \%)$ which are contrary to the findings of our study (boys $66.66 \%$ vs. girls $82.66 \%$ ). Another study carried out in a school in Wardha district ${ }^{5}$ found that $27.6 \%$ of the students had clean/combed hair as compared to $73.33 \%$ in the present study, while $29.7 \%$ of the students had clean/cut nails as opposed to $57.22 \%$ in the present study. In the present study girls fared better than boys when it came to clean teeth $(80.95 \%$ vs. $89.33 \%, \mathrm{p}<0.05)$, use of soap for hand washing at school $(72.38 \%$ vs. $86.66 \%$, p<0.05), hand washing after toilet $(80.95 \%$ vs. $93.33 \%$, p<0.05). Similar findings were observed in the South Kolkata study ${ }^{4}$. The most common morbidity among girls was clinically detected anemia (57.33\%) and underweight (30.66\%). For boys the most common morbidity was anemia (43.28\%), underweight (32.38\%) and vitamin A deficiency (26.66\%). The South Kolkata 4 study found that the most common morbidity for boys was clinically detected pallor (55.34\%) followed by undernutrition (40.78\%) and worm infestation (39.81\%) while among girls the most common morbidity was again clinically detected pallor (51.85\%). These findings are similar to our study. It was found that boys were more under weight than girls (32.38\% vs. 30.66\%). Similarly the South Kolkata ${ }^{4}$ study observed that boys were more undernourished than girls (40.78\% vs. $25.93 \%)$.

CONCLUSION AND RECOMMENDATION: The level of personal hygiene was found to be poor among the primary school children. The level of personal hygiene was found to be better in girls as compared to boys. Anemia and malnutrition was found to be common among the school children. The department of Community Medicine, Mamata Medical College, Khammam, regularly takes health education sessions in different schools and localities of Khammam but the government health services should regularly undertake school health checkup and health education session in the 


\section{ORIGINAL ARTICLE}

schools for a wider coverage. Periodic appraisal of school staff and parents of the school students needs to be undertaken in aspects of health of the children.

\section{REFERENCES:}

1. Govt. of India (1961). Report of school health committee, part-1, Central health education bureau, New Delhi.

2. Rama B. Varu. School Health Services in India: The social and economic context, Sage Publications Pvt. Ltd; 2008. P.1-2.

3. School water supply, Sanitation and Hygiene education: India technical Note Series, Ministry of Human Resource Development, Government of India, 2004.

4. Soumya Deb, Sinjita Dutta, Aparajita Dasgupta, Raghunath Mishra. Relationship of personal hygiene with nutrition and morbidity profile: A study among primary school children in South Kolkata. Indian J Community Med April 2010; p 280-284.

5. Dongre AR, Deshmukh PR, Garg BS. The impact of school health education program on personal hygiene and related morbidities in tribal school children of Wardha district. Indian J Community Med 2006; 31:81-2.

\section{AUTHORS:}

1. Aditya S. Berad

2. B. Chandra Sekhar Reddy

3. B.P. Ravi Kumar

4. Venu Bolisetti

\section{PARTICULARS OF CONTRIBUTORS:}

1. Associate Professor, Department of Community Medicine, Mamata Medical College, Khammam, A.P.

2. Assistant Professor, Department of Community Medicine, Mamata Medical College, Khammam, A.P.

3. Professor, Department of Community Medicine, Mamata Medical College, Khammam, A.P.
4. Senior Resident, Department of Community Medicine, Mamata Medical College, Khammam, A.P.

\section{NAME ADDRESS EMAIL ID OF THE CORRESPONDING AUTHOR:}

Dr. Aditya S Berad,

Department of Community Medicine, Mamata Medical College,

Khammam, A.P.

Email- adityasuryaberad@rediffmail.com

Date of Submission: 12/08/2013. Date of Peer Review: 13/08/2013. Date of Acceptance: 17/08/2013. Date of Publishing: 21/08/2013 